\section{RISUS - Journal on Innovation and Sustainability}

ISSN 2179-3565

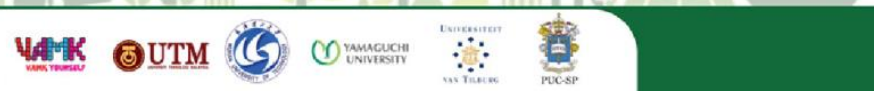

RISUS - Journal on Innovation and Sustainability volume 11, número 3 - 2020

ISSN: $2179-3565$

Editor Científico: Arnoldo José de Hoyos Guevara Editor Assistente: Rosa Rizzi Avaliação: Melhores práticas editoriais da ANPAD

\title{
A RANKING FOR THE SUSTAINABLE DEVELOPMENT GOALS FOCUSING ON THE 5PS
}

Um ranking para os objetivos de desenvolvimento sustentável com foco no 5Ps

Agris L. Dumpe, Arnoldo de Hoyos Guevara ${ }^{1}$ ${ }^{1}$ Pontificial Catholic University of Sao Paulo, Brazil E-mail: agrisjr@hotmail.com,dehoyos@pucsp.br

\begin{abstract}
Moving strategically toward the 2030 Agenda for Sustainable Development, the UN organized a Sustainable Development Solutions Network (UNSDSN) and a Platform (HLPF) in order to harness the so-called Data Revolution that could help to achieve systemically the 17 Goals, by attaining local and globally the corresponding targets. For this purpose, there is a need to keep joining efforts and know-how to develop an appropriate framework and roadmap. This paper represents a contribution for monitoring the SDG based on the 5Ps People, Planet, Prosperity, Peace and Partnership; by using data from the Iberoamerican Foresight Network Observatory (ORIBER).
\end{abstract}

Keywords: RIBER, SDGs, 5Ps, Ranking of countries.

\section{ACEITO EM: 10/03/2020}

PUBLICADO: 30/09/2020 


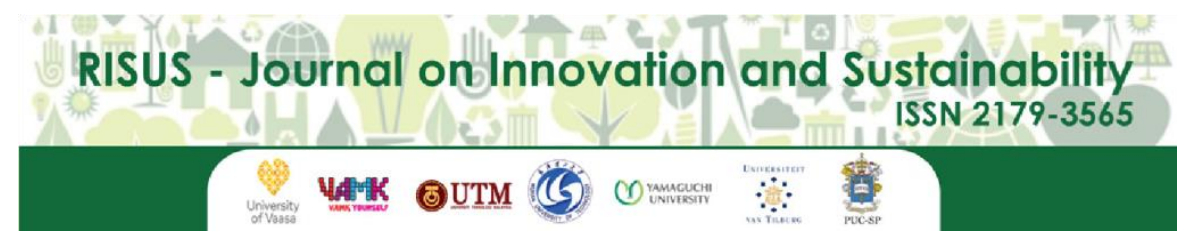

RISUS - Journal on Innovation and Sustainability volume 11, número 3 - 2020

ISSN: $2179-3565$

Editor Científico: Arnoldo José de Hoyos Guevara Editor Assistente: Rosa Rizzi Avaliação: Melhores práticas editoriais da ANPAD

\section{UM RANKING PARA OS OBJETIVOS DE DESENVOLVIMENTO SUSTENTÁVEL COM FOCO NO 5PS}

A ranking for the sustainable development goals focusing on the 5Ps

Agris L. Dumpe, Arnoldo de Hoyos Guevara ${ }^{1}$ ${ }^{1}$ Pontificial Catholic University of Sao Paulo, Brazil E-mail: agrisjr@hotmail.com, dehoyos@pucsp.br

\section{RESUMO}

Movendo-se estrategicamente para a Agenda 2030 para o Desenvolvimento Sustentável, a ONU organizou uma Rede de Soluções para o Desenvolvimento Sustentável (UNSDSN) e uma Plataforma (HLPF) para aproveitar a chamada Revolução de Dados que poderia ajudar a atingir sistematicamente os 17 Objetivos, através do alcance local e globalmente os alvos correspondentes. Para tal, é necessário continuar a unir esforços e know-how para desenvolver um quadro e um roteiro adequados. Este trabalho representa uma contribuição para o monitoramento dos ODS com base nos 5Ps Pessoas, Planeta, Prosperidade, Paz e Parceria; utilizando dados do Observatório da Rede Ibero-americana de Prospectiva (ORIBER).

Palavras-chave: RIBER, SDGs, 5Ps, Ranking de países. 


\section{INTRODUCTION}

There is a great need to consider ways to foster strategic foresight that may help, not only governments, but also the private sector and civil society to get involved collaboratively taking care of the present and future conditions regarding the five key development drivers related to the SDG : People, Planet, Prosperity, Peace and Partnership. On this paper we'll be presenting some of the alternatives going on that may contribute to the HighLevel Political Forum (HLPF, 2019) that is the central platform for follow-up and review of the 2030 Agenda for Sustainable Development, based on connecting studies regarding 15 Sustainable Development Challenges developed for the Iberoamerican region and the 5Ps. Our work, being interdisciplinary, may also contribute on harnessing insights regarding Social-Ecological Systems Research for Monitoring Sustainable Development as being developed at the Stockolm Resilience Center by Selomane et al (SELOMANE, 2019), particularly nowadys where think-thanks networks like the Millennium Project and Plataforms may become involved with EGovernance as recommended by the UN(UN, 2018); and already being implemented in places like Estonia (HEATH, 2019).

The SDGs could more easily reached if regionally institutional radars were developed so that farther futureoriented decision-making processes may be more effective. The futures-oriented information research has nothing to do with predictions or incremental trends. Forecasting and trends do not guarantee innovative ideas and disruptive innovation because they analyses the past to predict the future and relies on continuity. The landscape of analysis is now more volatile, uncertain, complex and ambiguous (VUCA) and needs disruptive answers that require anticipatory and collective intelligence systems. Actually the UN Inter-Agency and Expert Group on the SDG Indicators (IAEG-SDGs ${ }^{1}$ ) may be moving in that direction using new dashboards, frameworks and cross matrixes approaches, particularly now with the UNSDN fostering a Data Revolution (UNSDN, 2019), and the strong support of Jeffrey Sachs and the Sustainable Development Solutions Network (SACHS,2018).

Actually and as mentioned by Weitz (WEITZ, 2017), the Stockholm Environmental Institute (SEI) has being working in developing a practical approach for gaining a systemic and contextual perspective on the SDGs, that may help to understand interactions, synergies and trade-offs among them and hence strategically become more systemically efficient; and as indicated at $\mathrm{SEI}^{2}$ : How the Sustainable Development Goals (SDGs) interact with each other is a key question in the implementation of the 2030 Agenda. Understanding these interactions is vital for prioritizing action and anticipating knock-on effects. This kind of approach has already being tried focusing implementing the 2030 Agenda in Latin America by the independent Research Forum IRF (BARKET, 2017).

\section{The Iberoamerican Foresight Network - RIBER}

A few years ago (2014) an Iberoamerican Foresight Network - RIBER ${ }^{3}$ was started, as regional subgroup of the Millennium Project Think-Thank, with the purpose of joining forces helping the Iberoamerican Region to overcome development hardships seeking new ways to foster Sustainable Development, something that Jorge Máttar from CEPAL was also starting doing together with Daniel Perroti form ILPES at that time; and more recently (2016) these two organizations organized an International Course on Strategic Foresight for dealing with the UN SDGs consisting basically in : Defining the Problem and identifying the relevant variables concerning the structural system; develop alternative scenarios; and design and build up a strategic foresight sustainable development model. Moreover actually already a year before UN SDGs were defined, the RIBER had build up an Observatory $\left(\mathrm{ORIBER}^{4}\right.$ ) and was working on this kind of model based on 15 SDGs (GPS ), somehow related to the 17 UN SDGs as we are going to show next and applying to 132 countries divided into 3 Regions: Iberoamerican (AIBER, 21 countries) Advanced Economies (AVECO, 27 countries ) and Others (OTHERS, 84 countries ) SDGs Ranking of Countries based on the GPS through the 5 P's of Sustainable Development Goals (SDGs).

\footnotetext{
${ }^{1}$ https://unstats.un.org/sdgs/iaeg-sdgs/

${ }^{2}$ https://www.sei.org/projects-and-tools/projects/disentangling-interactions-sustainable-development-goals/

${ }^{3}$ https://www.pucsp.br/catedraignacysachs/riber.html

${ }^{4}$ https://www.pucsp.br/catedraignacysachs/oriber.html
} 
The first step was to relate the RIBER 15 SDGs to the 17 UN SDGs as shown in the following Table 1.

Table 1 Relating the RIBER 15 SDGs with the UN 17 SDGs

RIBER 15 SDGs

1 Basic Resources: Water, Food, Energyy

2 Shelter

3 Security and Peace

4 Health and Enviroment

5 Inequalities and Gender Social Inclusion

6 The Future of Work and Education

7 Productive Transformation and Sustainable Innovation

8 Integration and Startefic Alliances

9 Longevity Trends

10 Climate Change and Renwable Energies

11 Biodiversityu: Natural and Social Capital

12 Resilience

13 Democracy and SocialNetworks

14 Decocracy and Social Networks

15 Well-Being and Quality of Life

UM 17 SDGs

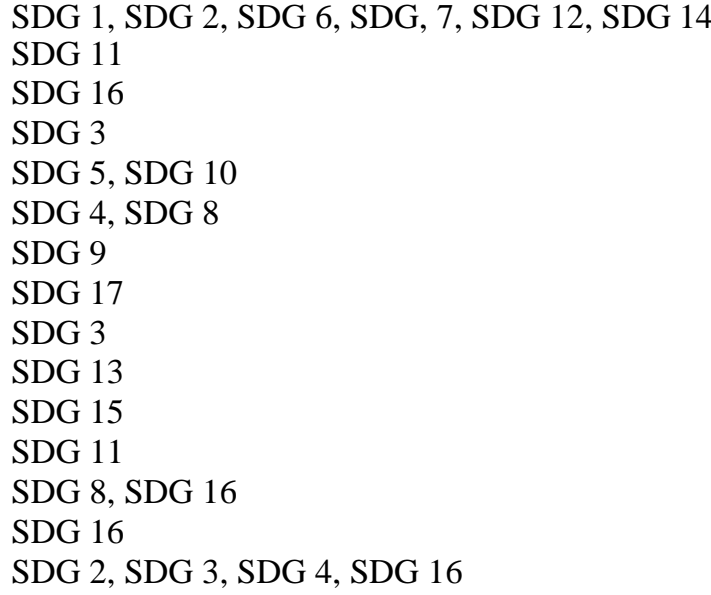

And also to relate the RIBER 15 SDGs with the synthetic UN 5Ps

P1. PEOPLE - End poverty and hunger in all forms and ensure dignity and equality. P2. PLANET - Protect our planet's natural resources and climate for future generations. P3. PROSPERITY - Ensure prosperous and fulfilling lives in harmony with nature.

P4. PEACE - Foster peaceful, just and inclusive societies

P5. PARTNERSHIP - Implement the agenda through a solid global partnership As shown in the following Table 2

Table 2 Relating the RIBER 15 SDGs to the UN 5 Ps

RIBER 15 SDGs

1 Basic Resources: Water, Food, Energyy

2 Shelter

3 Security and Peace

4 Health and Enviroment

5 Inequalities and Gender Social Inclusion

6 The Future of Work and Education

7 Productive Transformation and Sustainable Innovation

8 Integration and Startefic Alliances

9 Longevity Trends

10 Climate Change and Renwable Energies

11 Biodiversityu: Natural and Social Capital

12 Resilience

13 Democracy and SocialNetworks

14 Decocracy and Social Networks

15 Well-Being and Quality of Life
UM 17 SDGs
$\mathrm{P} 1, \mathrm{P} 2$
$\mathrm{P} 1, \mathrm{P} 2$
$\mathrm{P} 1, \mathrm{P} 3, \mathrm{P} 4$
$\mathrm{P} 1, \mathrm{P} 2, \mathrm{P} 5$
$\mathrm{P} 1, \mathrm{P} 3, \mathrm{P} 4, \mathrm{P} 5$
$\mathrm{P} 1, \mathrm{P} 3$
$\mathrm{P} 2, \mathrm{P} 5$
P1, P5
P1
P1, P2
P1, P2, P3
P1
P1, P3
P1, P3, P4, P5
P1, P2, P3 
Using these ideas it was possible, using multivariate analysis based on information ( hundreds of variables for 132 countries ) regarding the RIBER 15SDGs to build up a Global SD Ranking that allows in particular, to see how is The Iberoamerican Region - AIBER (21 Countries) doing when compared to a group of Advanced Economy Countries - AVECO (27 Countries) and Other Countries - OTHER (84 Countries ). The greatest difference among AVECO and the other two groups as may be seen in Fig. 3 clearly being regarding Partnership and in particular, Peace as it was to be expected and would need a special care.

A linear Model was built for each of the SDG 5Ps, by using Principal Component Analysis (PCs) and Stepwise Regression to select a give weights to the variables involved (Vars) that give raise to New Indicators( Nis ), find levels of simliarity ( Fig. 1 ) and build up rankings as shown in the next tables.

$$
\mathrm{NI}=\sum_{\mathrm{PCl}}^{\mathrm{PCn}} \mathrm{PCn} *((\mathrm{R}-\mathrm{Sq} * \operatorname{Var} 1)+(\mathrm{R}-\mathrm{Sq} * \operatorname{Var} 2)+\ldots .+(\mathrm{R}-\mathrm{Sq} * \operatorname{Var} \mathrm{n}))
$$

$\mathrm{NI}=\mathrm{New}$ Indicator

$\mathrm{PC}=$ Eigenvalue of principal component

$\mathrm{R}-\mathrm{SQ}=$ Corresponding $\mathrm{R}^{2}$ on the Variable on the Stepwise Regression

Figure 1 Relationships among the 5Ps

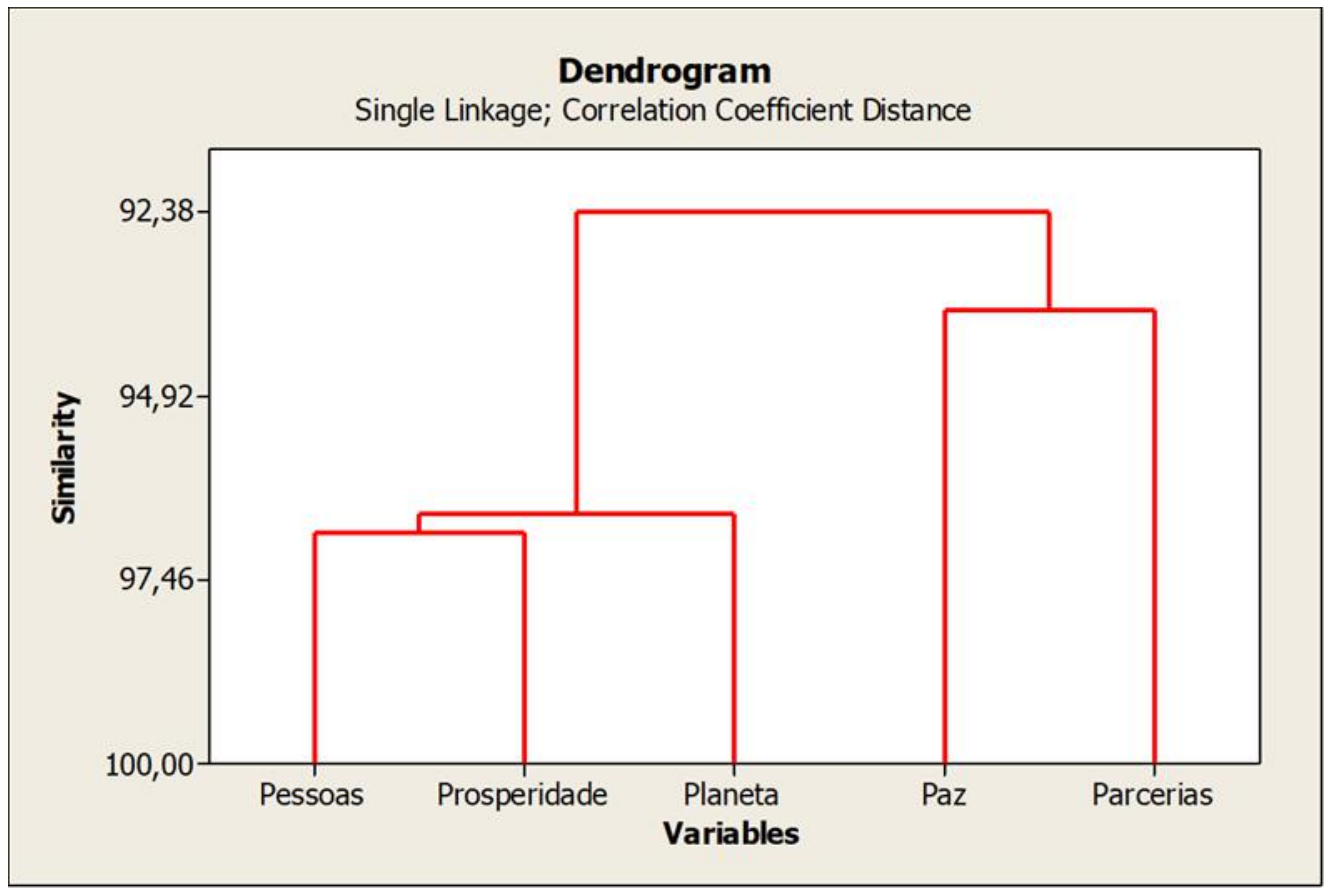

Table 3 People Ranking

\begin{tabular}{|c|c|c|c|c|c|}
\hline & BEST 10 & & & WORST 10 & \\
\hline Country & Ranking & Region & Coountry & Ranking & Region \\
\hline New Zealand & 100 & AVECO & Iraq & 19 & OTHERS \\
\hline Canada & 99 & AVECO & Pakistan & 17 & OTHERS \\
\hline Iceland & 97 & AVECO & Nigéria & 16 & OTHERS \\
\hline Norway & 97 & AVECO & Sudan & 12 & OTHERS \\
\hline Denmark & 96 & AVECO & Burundi & 12 & OTHERS \\
\hline Australia & 96 & AVECO & Guine & 12 & OTHERS \\
\hline Switzerland & 96 & AVECO & Yemen & 11 & OTHERS \\
\hline Netherlands & 95 & AVECO & Angola & 11 & OTHERS \\
\hline Finland & 94 & AVECO & Centr.Afri.Rep. & 6 & OTHERS \\
\hline Sweden & 94 & AVECO & Chad & 0 & OTHERS \\
\hline
\end{tabular}


Note. For Building the Model for People Ranking were used 5 Synthetic Indicators: Estimated GNI per capita Female, Estimated GNI per capita Male, IDH, GINI index e Social Progress Index; and other 23 other Variables: Maternal mortality rate, Stillbirth rate, Child mortality rate, Deaths from infectious diseases, Life expectancy, Non-communicable disease deaths between the ages of 30 and 70, Obesity rate, Suicide rate, Women treated with respect, Tolerance for immigrants, Tolerance for homosexuals, Discrimination and violence against minorities, Religious tolerance, Health expenditure, public, External resources for health, Gender Inequality Index Value, Share of seats in parliament, Life expectancy at birth Female, Life expectancy at birth Male, Mean years of schooling Female, Mean years of schooling Male, Expected years of schooling Female, Expected years of schooling Male.

Table 4 Planet Ranking

\begin{tabular}{|c|c|c|c|c|c|c|}
\hline \multicolumn{3}{|c|}{ BEST 10 } & \multicolumn{4}{|c|}{ WORST 10} \\
\hline Country & Ranking & Region & Coountry & Ranking & & Region \\
\hline Switzerland & 89 & AVECO & Mozambique & & 9 & OTHERS \\
\hline Norway & 87 & AVECO & Madagascar & & 8 & OTHERS \\
\hline France & 87 & AVECO & Niger & & 7 & OTHERS \\
\hline Australia & 87 & AVECO & Congo Rep. & & 7 & OTHERS \\
\hline Sweden & 87 & AVECO & Chad & & 6 & OTHERS \\
\hline Canada & 86 & AVECO & Benin & & 6 & OTHERS \\
\hline Germany & 86 & AVECO & Ghana & & 5 & OTHERS \\
\hline Japan & 85 & AVECO & Tanzania & & 1 & OTHERS \\
\hline Czech Rep. & 85 & AVECO & Togo & & 0 & OTHERS \\
\hline
\end{tabular}

Note. For Building the Model for People Ranking were used 5 Synthetic Indicators: EV - Water Resources, EV - Agriculture, EV - Forests, EV - Fisheries, Ocean Health Index Score; and other 18 Variables: Access to piped water, Rural vs. urban access to improved water source, Access to improved sanitation facilities, Availability of affordable housing, Access to electricity, Quality of electricity supply, Indoor air pollution attributable deaths, Outdoor air pollution attributable deaths, Greenhouse gas emissions, Water withdrawals as a percent of resources, Biodiversity and habitat, Renewable internal freshwater resources per capita, Electric power consumption, Alternative and nuclear energy, Combustible renewables and waste, Fossil fuel energy consumption, Population growth, Population total.

Table 5 Prosperity Ranking

\begin{tabular}{|c|c|c|c|c|c|}
\hline & BEST 10 & & & WORST 10 & \\
\hline Country & Ranking & Region & Coountry & Ranking & Region \\
\hline Norway & 100 & AVECO & Laos & 10 & OTHERS \\
\hline Sweden & 99 & AVECO & Tajikistan & 10 & OTHERS \\
\hline Netherlands & 98 & AVECO & Rwand & 10 & OTHERS \\
\hline Finland & 97 & AVECO & Sudan & 9 & OTHERS \\
\hline New Zealand & 95 & AVECO & Guinea & 8 & OTHERS \\
\hline Canada & 93 & AVECO & Mauritania & 5 & OTHERS \\
\hline Iceland & 93 & AVECO & Pakistan & 4 & OTHERS \\
\hline Switzerland & 92 & AVECO & Centr.Afr.Rep. & 4 & OTHERS \\
\hline Denmark & 92 & AVECO & Iraq & 4 & OTHERS \\
\hline South Korea & 90 & AVECO & Chad & 0 & OTHERS \\
\hline
\end{tabular}

Note. For Building the Model for Prosperity Ranking were used 6 Synthetic Indicators: Well-being, Political rights, Freedom of movement, Freedom of religion, Modern slavery human trafficking and child marriage, Inequality in the attainment of education; and other 16 variables: Adult literacy rate, Primary school enrollment, Lower secondary school enrollment, Upper secondary school enrollment, Mobile telephone subscriptions, Internet users, Press Freedom Index, Freedom of speech, Private property rights, Freedom over life choices, Satisfied demand for contraception, Years of tertiary schooling, Women's average years in school, Number of globally ranked universities, Unemployment total, Total Labor Force. 
Table 6 Peace Ranking

\begin{tabular}{|c|c|c|c|c|c|c|c|}
\hline \multicolumn{3}{|c|}{ BEST 10} & & \multicolumn{4}{|c|}{ WORST 10} \\
\hline Country & Ranking & & Region & Coountry & Ranking & & Region \\
\hline Denmark & & 100 & AVECO & Nigeria & & 10 & OTHERS \\
\hline Finland & & 99 & AVECO & Congo Rep. & & 10 & OTHERS \\
\hline Sweden & 98 & & AVECO & Tajikistan & 10 & & OTHERS \\
\hline New Zealand & 97 & & AVECO & Venezuela & 9 & & OTHERS \\
\hline Noerway & 95 & & AVECO & Cambodia & 8 & & OTHERS \\
\hline Switzerland & 93 & & AVECO & Uzbekistan & 5 & & OTHERS \\
\hline Canada & 93 & & AVECO & Yemen & 4 & & OTHERS \\
\hline Netherlands & 92 & & AVECO & Chad & 4 & & OTHERS \\
\hline Australia & 92 & & AVECO & Iraq & 4 & & OTHERS \\
\hline Iceland & 90 & & AVECO & Sudan & 0 & & OTHERS \\
\hline
\end{tabular}

Table 7 Alternative Peace Ranking using the Global Peace Index - GPI

\begin{tabular}{|c|c|c|c|c|c|}
\hline \multicolumn{3}{|c|}{ BEST 10} & \multicolumn{3}{|c|}{ WORST 10} \\
\hline Country & Ranking & Region & Coountry & Ranking & Region \\
\hline Iceland & 100 & AVECO & Russia & 18 & OTHERS \\
\hline New Zealand & 96 & AVECO & Central Afr.Rep. & 15 & OTHERS \\
\hline Austria & 93 & AVECO & Dem.Rep.Congo & 14 & OTHERS \\
\hline Portugual & 91 & AVECO & Libya & 13 & OTHERS \\
\hline Denmark & 90 & AVECO & Yemen & 12 & OTHERS \\
\hline Canada & 89 & AVECO & Somalia & 9 & OTHERS \\
\hline Czech Rep. & 89 & AVECO & Iraq & 7 & OTHERS \\
\hline Singapore & 89 & AVECO & South Sudan & 4 & OTHERS \\
\hline Japan & 88 & AVECO & Afghanistan & 1 & OTHERS \\
\hline Irreland & 88 & AVECO & Syria & 0 & OTHERS \\
\hline
\end{tabular}

Table 8 Partnership Rankig

\begin{tabular}{lrllll}
\hline & BEST 10 & & & WORST 10 \\
\hline Country & Ranking & Region & Coountry & Ranking & Region \\
UK & 100 & AVECO & Uzberkistan & OTHERS \\
Switzerland & 100 & AVECO & Burundi & 13 & OTHERS \\
Sweden & 99 & AVECO & Mali & 13 & OTHERS \\
Canada & 98 & AVECO & Togo & 12 & OTHERS \\
U.S. & 97 & AVECO & Angola & 11 & OTHERS \\
Denmark & 96 & AVECO & Pakistan & 9 & OTHERS \\
Australia & 94 & AVECO & Yemen & 7 & OTHERS \\
Finland & 93 & AVECO & Venezuela & OTHERS \\
Norway & 93 & AVECO & Guinea & OTHERS \\
New Zealand & 93 & AVECO & Sudan & OTHERS \\
\hline
\end{tabular}

Figure 2 Comparing the 5Ps Using ANOVAs for the 3 Regions

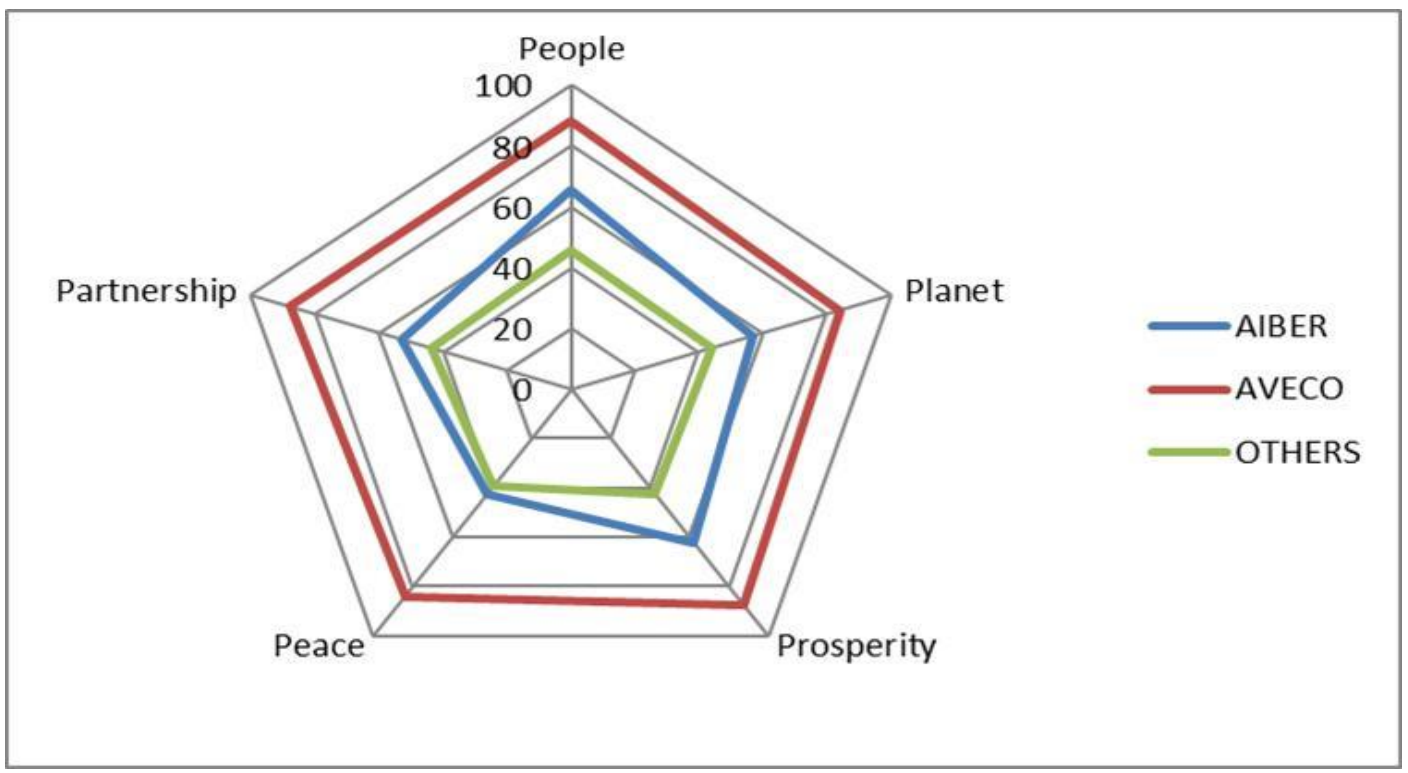


As may be seen in Figure 2 the greatest differences among AVECO and the other two groups are clearly Partnership and in particular Peace, as it was to be expected and would need a special care.

\section{CONCLUSION}

No doubt all 5Ps are basic but it may depend on the region as well as how critical is the timing regarding climate, that the UN Climate Action Summit 2019 that will be working in New York next September 23; as a matter of fact UN Secretary Antonio Guterres is pressing the countries representatives for realistic plans to reduce greenhouse gas emissions by $45 \%$ over the next decade, by means of full transformation of economies in line with sustainable development goal since. uneven growth, rising debt levels, possible upticks in financial volatility, and heightened global trade tensions are hampering progress on reaching the Sustainable Development Goals (UN,2019). This is reinforced by the Energy Transition Commission (ETC, 2018) very recent report Mission Possible declaring that full decarbonization is technically feasible with technologies that already exist and could cost less than $0.5 \%$ of Global GDP, but it could take longer due to uneven growth. So there is still some questions like to what extent will the poor countries benefits form the COP24 (BARAKAT, 2019).

The question is if the present geopolitical deglobalizing crisis that is going on, as well as the impacts on local unstable governments, will allow to actually develop and implement Strategic Foresight Planning focusing Sustainable Development, before is too late. This means changing Mind Sets of present day Governance, and perhaps moving into what it is now called Society 5.0, an idea that came from Japan that helps to develop human strengths and values as mentioned by Seiichi Matsuo (MATSUO, 2019), President of Nagoya University, and represents an Advanced Educational approach ${ }^{5}$. For this purpose, some projects like Teach the Future develop by the Futurist Peter Bishop ${ }^{6}$ and Transforming the Future by Riel Miller (MILLER, 2018) as well as groups like the Resilience Alliance ${ }^{7}$, the Stockholm Enviromental Institute (SEI), and the World Economic Forum (WEF) ${ }^{8}$ may be of some help.

\section{REFERENCES}

BARAKAT S., ENDALEW, E. J. LDCs, Negotiations and the Climate Crisis: Will the Poorest Countries Benefit from the COP24 Climate Package? [M]. IIED, 2019.

BARKET, K. Lessons from Latin America on Implementing the 2030 Agenda: Learning from a Regional Retreat [M]. Independent Research Forum IRF, 2017.

HLPF. UN High-Level Political Forum on Sustainable Development [M]. 2019.

ETC. Mission Possible: Reaching Net-zero Carbon Emissions from Harder-to-abate Sectors by Midcentury[M]. ETC, 2018.

HEATH, N. How Estonia Became an E-Government Powerhouse [M]. TechRepublic, 2019

UNSDN. Indicators and Monitoring Framework for SDGs/Launching a Data Revolution [M]. UNSDN, 2019.

MATSUO, S. The Educational Philosophy of a Nobel Prize factory [M]. Intelligence on Global Japan, 2019. Miller, R. Transforming the Future. Anticipation in the 21st Century [B]. Taylor Francis, 2018.

\footnotetext{
${ }^{5} \mathrm{https}: / /$ www.globaljapan.world/article/japan-leads-world-in-education-for-society-5-0/

${ }^{6} \mathrm{http}: / / \mathrm{www}$. teachthe future.org

${ }^{7} \mathrm{http}: / / \mathrm{www}$. resalliance.org

${ }^{8} \mathrm{https}$ ///www.weforum.org/whitepapers/from-funding-to-financing-transforming-sdg-finance-for-country-success.
} 
SACHS, J. et al. SDG Index and Dashboards Report [M]. New York: Bertelsmann Stiftung and Sustainable Development Solutions Network (SDSN), 2018.

SELOMANE, O. et al. Harnessing Insights from Social-Ecological Systems Research for Monitoring Sustainable Development [J]. Sustainability, 2019, 11(4), 1-36.

UN. Financing for Sustainable Development Report [M]. UN, 2019.

UN. Gearing E-Government to Support Transformation towards Sustainable and Resilient Societies [M]. EGOVERMENT SURVEY, 2018.

WEITZ, N. et al. Towards Systemic and Contextual Priority Setting for Implementing the 2030 Agenda [M]. Sustainability Science, 2017. 